\title{
Performance of Nutmeg (Myristica fragrans) Post Harvest and Marketing in East Halmahera Regency
}

\author{
Asmanur Jannah, Sari Anggarawati, Sunardi Sunardi*, and Isnain Turuy \\ Faculty of Agriculture Nusa Bangsa University \\ *Corespondent Author. Email : sunardiraharjo@gmail.com
}

\begin{abstract}
Nutmeg (Myristica fragrans) is an evergreen tree indigenous to Banda Island of Indonesia. In 2018 nutmeg production in Indonesia was 36,242 tons from 202,325 ha land, whereas the biggest production from the center production i.e. North Maluku Province. The aim of the study was to determine the performance of nutmeg postharvest and marketing at the farmer level in East Halmahera Regency. Data were obtained from thirty farmers as respondents with a purposive sampling method using questionnaires. Quantitative data were analyzed descriptively. Observation components were included the weight of nutmeg, fruit flesh, wet nutmeg, dry nutmeg, wet mace, and dry mace. The results showed that harvesting in this area was carried out 2-3 times a year. The harvest period is January-August, March-September and April-December with the average production in each harvest time was 1-4 kg per tree. Nutmeg was harvested using a pole and all fall nutmeg were collected. About $70 \%$ of farmers processed the nutmeg directly after harvesting. The main postharvest procession was separating and drying the nutmeg. The nutmeg was separated into three parts, i.e., the nutmeg pulp, seed, and mace. The drying procession was carried out by $60 \%$ of farmers that were different for each part, the nutmeg seed need 5-6 days and the mace need 1 day under sunshine. The range of nutmeg fruit components was varied with nutmeg pulp of $85.64-88.69 \%$, fresh seeds of $9.45-12.04 \%$, dry seeds of $6.45-8.28 \%$, fresh mace of $1.40-2.51 \%$ and dry mace of $0.66-1.46 \%$. Nutmeg seeds are sorted and graded by separating whole, wrinkled and crushed seeds. Marketing channels consist of village collectors, traders at Maba city and traders from outside the district, generally from Ternate. All harvested products were sent to Ternate in the form of seeds and mace.
\end{abstract}

Keywords: Postharvest, Nutmeg, Mace, Flesh, Marketing chain.

\section{INTRODUCTION}

Indonesia is the largest exporter of nutmeg and mace seeds that dominate $75 \%$ of the world market share. The nutmeg export value in 2020 increased about 16\% compared to the period January - April 2019. According to the Central Statistics Agency (BPS), national nutmeg production reached 37.4 thousand tons in 2020 [1]. The center of nutmeg production in Indonesia are North Maluku, Maluku, Aceh, North Sulawesi, and West Papua provinces. North Maluku has the largest area of nutmeg plantation reaches 42,716 ha and produces 7,937 tons.

East Halmahera regency in North Maluku Province has the opportunity to increase the nutmeg quantity and quality. Nutmeg area was increased from 1,590 $\mathrm{Ha}$ in 2015 to 2,762 Ha in 2019, but nutmeg production tends to decrease from 677 tons in 2015 to 175 tons in 2019 [2].

Most of Indonesia's nutmeg (99\%) is produced by community plantations or forests with simple cultivation techniques, post-harvest handling and modest equipment [3]. The problem is the low quantity and quality nutmeg production affects the price and its competitiveness in the world market. The main reason for nutmeg's low quality is the various nutmeg types, harvest timing, post-harvest handling, improper storage and packaging, and aflatoxin contamination [4]. Young nutmeg harvest resulted in a wrinkled seed. On the other side, improper drying, packaging, and storage resulted in fungi growth that increased aflatoxin contamination. The Indonesian nutmeg rejection by European Union countries because aflatoxins contamination exceeded the permissible threshold level in 2010-201. Aflatoxin contamination is found at every level of the domestic 
market chain, from farmers, collectors to exporters. Aflatoxin content in nutmeg seeds can be suppressed with proper handling since harvest, post-harvest, drying, packaging, and storage. The drying stage has the greatest influence on the nutmeg seeds quality. The nutmeg seed moisture content must maintain at less than $10 \%$, with storage in a cold and very dry room with $65 \%$ humidity [5].

The guidelines of good and correct nutmeg cultivation and postharvest technology already available for farmers, farmer groups, field officers, and business actors. The guidelines refer to the Good Agricultural Practices (GAP) and Good Handling Practices (GHP) principles to produce good quality nutmeg seeds and mace [4]. The implementation of GAP and GHP is a guarantee for consumers that the products are obtained from efficient, productive, and environmentally friendly processes. Thus, farmers will get added value from the price increases and adequate market guarantees.

The research objective was to determine the performance of nutmeg postharvest and marketing at the farmer level in East Halmahera Regency

\section{METHOD}

This research was conducted in East Halmahera Regency, North Maluku Province from October to December 2020. Data was collected through a survey by using a questionnaire to 30 respondents. Respondents were determined by a purposive sampling method. As many as 10 farmers were randomly selected to measure their nutmeg yields. The nutmeg fruit samples were
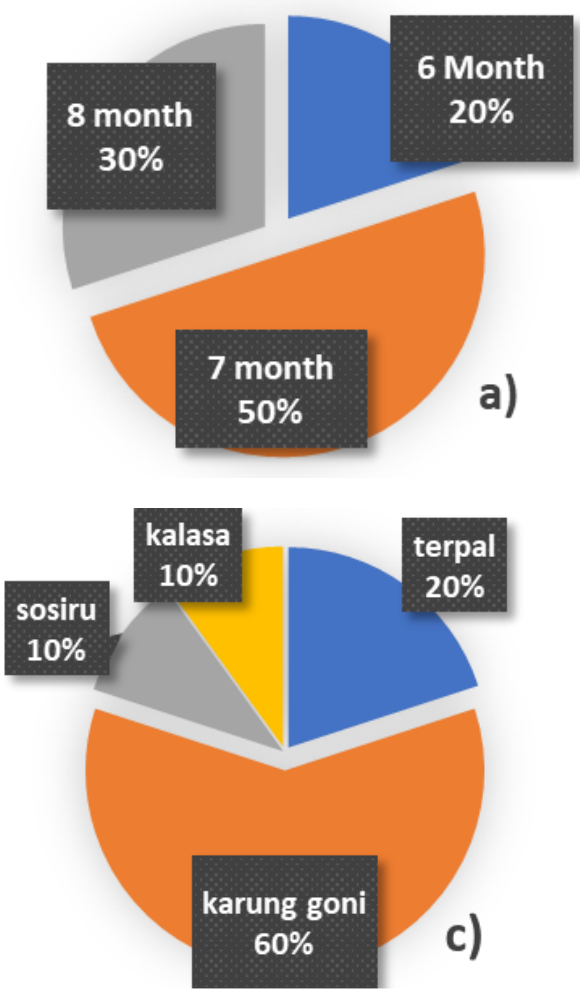

Figure 1. Harvest and Postharvest at research area: a) nutmeg harvest age, b) the result of nutmeg harvest of each tree, c) drying pad and d) drying length taken 3 times of $1 \mathrm{~kg}$ from each tree. The nutmeg sample was peeled, and its components were separated, i.e.: nutmeg flesh, nutmeg seeds, and mace. The fresh weight of each part was weighed and dried under the sun based on the farmers' methods.

Data were analyzed using descriptive qualitative, and quantitative methods. Quantitative analysis was conducted on nutmeg component through tabulated the mean and standard deviation. Qualitative analysis was conducted through traced back of marketing institution from village to province level and completed with marketing channel analysis.

\section{RESULT AND DISCUSSION}

\subsection{Farmer Characteristic}

The results showed that $60 \%$ of the age of nutmeg farmers in East Halmahera were of productive age (2050 years) with $100 \%$ own land ownership status. Most of the respondents had elementary school education (60\%), and only $10 \%$ of high school and $30 \%$ of undergraduate. This condition affects the farmer's mindset in plantation management and activities. In addition, education will influence farmers in absorbing and applying the latest nutmeg cultivation and postharvest technology.

The farmers nutmeg land ownership is varying between $1-5$ ha (60\%), 5-10 ha (20\%) and 10-15 ha $(20 \%)$. The number of nutmeg trees varies from 60 to 1500 trees in the farmer's garden depending on the size of the garden. The nutmeg spacing used is $8 \times 8 \mathrm{~m}^{2}$
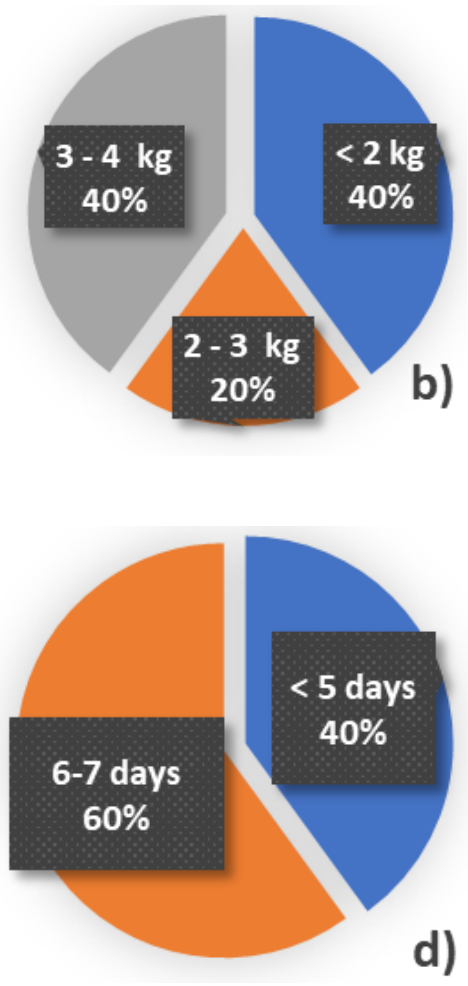
Table 1. Average of nutmeg component percentage in East Halmahera

\begin{tabular}{|l|l|l|l|l|l|}
\hline Farmer & \multicolumn{1}{|c|}{ Pulp (\%) } & \multicolumn{1}{|c|}{ Fresh seed (\%) } & \multicolumn{1}{|c|}{ Fresh mace (\%) } & \multicolumn{1}{|c|}{ Dry seed (\%) } & \multicolumn{1}{|c|}{ Dry mace (\%) } \\
\hline 1 & $87.01 \pm 1.50$ & $10.85 \pm 1.55$ & $2.15 \pm 0.30$ & $7.57 \pm 0.94$ & $1.06 \pm 0.15$ \\
\hline 2 & $88.69 \pm 0.97$ & $9.50 \pm 0.79$ & $1.81 \pm 0.18$ & $6.91 \pm 0.34$ & $1.09 \pm 0.27$ \\
\hline 3 & $88.10 \pm 0.36$ & $9.65 \pm 0.23$ & $2.25 \pm 0.55$ & $6.45 \pm 0.26$ & $1.16 \pm 0.23$ \\
\hline 4 & $88.13 \pm 0.13$ & $9.45 \pm 0.12$ & $2.42 \pm 0.20$ & $6.53 \pm 0.20$ & $1.16 \pm 0.15$ \\
\hline 5 & $86.71 \pm 0.17$ & $10.78 \pm 0.03$ & $2.51 \pm 0.14$ & $7.64 \pm 0.24$ & $1.36 \pm 0.12$ \\
\hline 6 & $85.64 \pm 0.69$ & $11.90 \pm 0.59$ & $2.45 \pm 0.11$ & $8.19 \pm 0.39$ & $1.29 \pm 0.10$ \\
\hline 7 & $86.00 \pm 1.00$ & $11.65 \pm 1.09$ & $2.36 \pm 0.11$ & $8.09 \pm 0.92$ & $1.46 \pm 0.06$ \\
\hline 8 & $86.07 \pm 1.84$ & $12.04 \pm 1.33$ & $1.90 \pm 0.55$ & $8.28 \pm 1.30$ & $0.96 \pm 0.25$ \\
\hline 9 & $86.64 \pm 0.10$ & $11.96 \pm 0.20$ & $1.40 \pm 0.11$ & $8.27 \pm 0.22$ & $0.66 \pm 0.06$ \\
\hline 10 & $86.81 \pm 0.15$ & $11.57 \pm 0.21$ & $1.63 \pm 0.05$ & $8.04 \pm 0.10$ & $0.90 \pm 0.01$ \\
\hline
\end{tabular}

(50\%), $7 \times 7 \mathrm{~m}^{2}(30 \%)$ and $5 \times 5 \mathrm{~m}^{2}(20 \%)$. The result showed that the spacing is varies depending on the distance between plants and other mixed plants. All farmers used a mixed cropping pattern with coconut, clove, areca nut, cocoa, and banana trees. Most of the farmers cultivate the banana and coconut trees on nutmeg land. Most of the farmers used patani varieties $(60 \%)$, the rest used forest nutmeg varieties or a mixture of forest nutmeg and patani nutmeg. Patani nutmeg and forest nutmeg are 2 types of nutmeg that are widely planted by farmers from 8 types of nutmeg found in Maluku [6]

\subsection{Nutmeg Harvest and Postharvest}

The distribution of nutmeg plant age was 10 years old about 50\%, 10-15 years old about $40 \%$, and more than 15 years old $(10 \%)$. These results were different with [7] that reported productive nutmeg age was 20-30 years old at Kamal Village, 20-35 years old at Nuruwe Village and 25-35 years old at Lohiatala Village. BPS of North Maluku Province (BPS Maluku Utara, 2020; BPS Maluku Utara, 2016) stated that the increase of nutmeg plantation area began from 1.590 ha in 2015 and reached 2.762 ha in 2019. Therefore, most nutmeg plants age about 5-6 years old at the data collected.

Most of the respondents harvested nutmeg at the age of 7 months (50\%), 6 months (20\%) and 8 months $(30 \%)$ after flowering (Figure 1). The fruit's age affects the nutmeg and mace seeds' quality. Harvesting too young nutmeg will cause wrinkles. According to the guidelines for nutmeg postharvest handling (Ministerial Regulation No. 53/2012, 2012), ideally, nutmeg harvesting is done at 9 months old after flowering, with the signs were brownish-yellow markings on the nutmeg, dark brown to black seeds shells, and red mace. But the economic factor is usually the reason for earlier nutmeg harvest time [8].

The harvesting frequency is done 2 times (80\%), the rest is 3 times a year. Harvest periods were January-
August, March-September, and April-December. The highest production was obtained in April-September. The nutmeg production was varied for each tree. The result showed that $60 \%$ of respondents reported about 3 - $4 \mathrm{~kg}$ nutmeg per tree at each harvest. The rest is less than $2 \mathrm{~kg}$. The number of fruits ranges from 12-16 per kilogram depending on the nutmeg size. The size was influenced by the nutmeg type, plant age, spacing (density), and plant maintenance. The ideal nutmeg plant spacing is $10 \times 10 \mathrm{~m}$, because the crown growth resembles plant material from seeds [5]. The plant distance of about $5 \times 5 \mathrm{~m}$ or $6 \times 6 \mathrm{~m}$ resulted in shorter plant growth.

Nutmeg is harvested by dropping it using a hooked bamboo pole. The harvested nutmeg is collected and mixed with the fallen nutmeg. Mixing harvested nutmeg with the fallen nutmeg will reduce the nutmeg and mace seed quality. Nutmeg postharvest processing was meat, nutmeg, and mace separation. Some farmers process it directly $(70 \%)$, while others $(30 \%)$ store the nutmeg for 3-4 days. This process did not follow the guidelines of Minister of Agriculture, RI number No. 53 year 2012 about nutmeg post-harvest handling.

Nutmeg and mace drying is done under the sun. Some farmers use tarpaulins or sacks for drying nutmeg seeds, while mace use winnows. There were $60 \%$ of farmers drying nutmeg seeds for 6-7 days and one day for mace. Sorting and grading of nutmeg seeds are done by separating whole, wrinkled and crushed seeds. The guideline of nutmeg postharvest handling instructed to use more than 9 days to reduce the moisture content to less than $10 \%$ [6]. Less moisture will increase nutmeg seed quality that minimizes fungi growth that can cause aflatoxin contamination [5]. Dried seeds and mace are usually put in sacks or plastic and stored in kitchens and para-para $(60 \%)$, warehouses $(20 \%)$, and living rooms (20\%).

The pulp component ranges from 85.64-88.69\%, fresh seeds between $9.50-12.04 \%$, and fresh mace was $1.4-2.5 \%$ (Table 1.). The nutmeg pulp percentage is 
Table 2. Nutmeg Harvest Quantity, Seed, and Mace Price Based on Marketing Channel

\begin{tabular}{|l|l|l|l|l|l|}
\hline \multirow{2}{*}{$\begin{array}{c}\text { Marketing } \\
\text { Channel }\end{array}$} & \multirow{2}{*}{ Farmer } & \multicolumn{2}{|c|}{ Seed } & \multicolumn{2}{c|}{ Mace } \\
\cline { 3 - 6 } & & Quantity (Kg) & Price (Rp) & Quantity (Kg) & Price (Rp) \\
\hline I & $30 \%$ & $<50$ & $55.000-60.000$ & $<15$ & $200.000-215.000$ \\
\hline$I I$ & $50 \%$ & $50-170$ & $60.000-70.000$ & $15-50$ & $215.000-230.000$ \\
\hline$I I I$ & $20 \%$ & $>200$ & 95.000 & $>85$ & 260.000 \\
\hline
\end{tabular}

higher than the seed due to the nutmeg maturity level. The immature nutmeg resulted in low dry matter content because of the physiologically immature seed. Therefore, it will produce shrunken or wrinkled seeds [9].

\subsection{Nutmeg Seed and Mace Marketing}

Nutmeg seeds and mace are sold through three marketing channels, i.e. village collectors, to collectors in Maba City and sellers to Ternate traders. The three marketing channels can be described in Figure 2. Marketing channel consists: a. Channel I: Farmer - Village collectors -Maba City Traders-Ternate traders

b. Channel II: Farmer - Maba City traders-Ternate traders

c. Channel III: Farmer - Ternate traders

The marketing channel was selected by farmers based on harvesting results. In the low harvest quantity, farmers would sell it through village collectors, while in the high quantity (more than $200 \mathrm{~kg}$ ) they could invite Ternate traders to pick the product (Table 2).

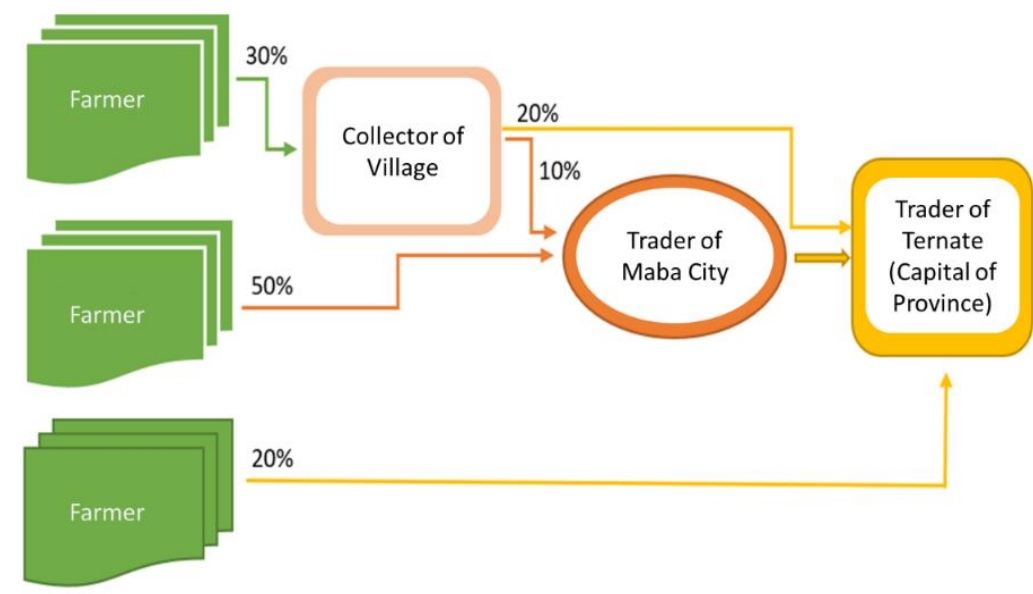

Figure 2. Nutmeg Seed and Mace Marketing Channel in East Halmahera

Farmers with small harvests are more profitable to sell nutmeg to Village Traders because they could waive transportation fees to bring to Maba City. For higher harvest quantity, farmers choose to sell it to traders in Maba City because there is a higher selling price and the transportation costs could be covered by sales margin. Meanwhile, farmers with more than $200 \mathrm{~kg}$ yields, Ternate traders come to farmers and offer higher selling prices. Through this channel, traders could cut the marketing chain and guarantee to get goods directly from farmers.

\section{CONCLUSION}

1. Farmers in East Halmahera harvest 2-3 times a year with the period January-August, March-September, and April-December, the average fruit production of $1-4 \mathrm{~kg}$ per tree per harvest.

2. Nutmeg is harvested using a pole and collected with the nutmeg that falls from the tree. Some farmers process it directly $(70 \%)$, while others $(30 \%)$ store the nutmeg for 3-4 days. There were $60 \%$ of farmers drying nutmeg seeds for 6-7 days and one day for mace. All farmers dry nutmeg and mace under the sun. 
3. The pulp component ranges from $85.64 \%$ to $88.69 \%$, fresh seeds between 9.50 and $12.04 \%$, the fresh mace of $1.4-2.5 \%$, dry seeds of $6.45-8.28 \%$, and dry mace of $0.66-1.46 \%$.

4. Nutmeg seeds and mace are sold through three marketing channels, i.e. village collectors, to collectors in Maba City, and sellers to Ternate traders.

\section{REFERENCES}

[1] Databoks. (2021). Maluku Utara Pimpin Produksi Pala Nasional pada 2020. https://databoks.katadata.co.id/datapublish/2021/06 /02/maluku-utara-pimpin-produksi-pala-nasionalpada-2020

[2] BPS Maluku Utara. (2020). Provinsi Maluku Utara dalam Angka 2020. Badan Pusat Statistik Provinsi Maluku Utara;BPS Maluku Utara. (2016). Provinsi Maluku Dalam Angka 2016. Badan Pusat Statistik Provinsi Maluku Utara

[3] Fauziyah, E., Kuswantoro, D. P., \& -, S. (2015). Prospek Pengembangan Pala (Myristica fragrans Houtt) di Hutan Rakyat. Jurnal Ilmu Kehutanan, 9(1), 32. https://doi.org/10.22146/jik.10182

[4] Hafif, B. (2021). The Strategy to Maintain Indonesia as a Main Nutmeg Producer in the World. Jurnal Penelitian Dan Pengembangan Pertanian, 40(1), 58-70.

[5] Supriadi. (2017). Aflatoxin of nutmeg in indonesia and its control. Perspektif, 16(2), 102-110. https://doi.org/10.21082/psp.v16n2.2017.102-110

[6] Dinar, L., Suyantohadi, A., \& Fajar F, M. A. (2013). Kajian Standar Nasional Indonesia Biji Pala. Jurnal Standardisasi, 15(2),

83. https://doi.org/10.31153/js.v15i2.111

[7] Rehatta, H., Wattimena, A. Y., \& Tupamahu, F. (2016). Study on Nutmeg Productivity Pala (Myristica sp.) in Western Kairatu Sub-District, Western Ceram District. J. Budidaya Pertanian, 12(1), 51-54.

[9] Copeland, L. O., \& McDonald, M. B. (2001). Principles of Seed Science and Technology. Springer US. https://doi.org/10.1007/978-1-46151619-4

[8] Kementerian Pertanian. (2012). Peraturan Menteri Pertanian Republik Indonesia Nomor 53/Permentan/OT.140/9/2012 Tentang Pedoman Penanganan Pascapanen Pala. Kementrian Pertanian. RI. 